\title{
KNOWLEDGE MANAGEMENT STOCKS IN SERBIAN SMALL AND MID-SIZED ENTERPRISES
}

\author{
Vojislav Babić, PhD \\ University of Belgrade, Institute for Sociological Research \\ 18 Cika Ljubina Street, 11000 Belgrade, Serbia, \\ Phone: +38163334067, e-mail: babic.voja@gmail.com \\ Prof. Siniša Zarić, PhD \\ University of Belgrade, Faculty of Economics \\ 6 Kamenicka Street, 11000 Belgrade, Serbia, \\ Phone: +38163254525, e-mail: sinisha.zaric@gmail.com
}

\section{ABSTRACT}

The study measures and analyzes the representation level of the knowledge management (KM) strategy in Serbian enterprises. KM is the skill of acquiring and allocating knowledge resources in order to achieve greater business efficiency and profitability of enterprises. The paper starts from Romer's $(1986,2018)$ theory of increasing yields. According to Romer, a stable growth is the result of endogenous accumulation of knowledge. The aim of this paper is to determine the extent to which elements of KM are represented in small and mid-sized Serbian enterprises. The instrument that was constructed for measuring KM contained 11 variables, categorized into 5 complex indicators: academic education, employee training, storage, dissemination and technical support. An online questionnaire with closed responses, interval and Likert scales was used for collecting the data. The survey was conducted on the sample of 157 enterprises in 15 Serbian cities, 60 of which were small and 34 mid-sized enterprises. The data were processed by the 'custom tables with column proportion of significance' statistical technique. Based on the results for small and mid-sized enterprises, measurement indicators such as employee training, dissemination and technical support show a positive level, while the 'storage' and 'academic education' indicator have a partial presence of KM stocks. When it comes to small enterprises, in terms of individual variables that are a constituent part of indicators, the largest stocks of KM were measured with the variable 'number of employees with bachelor's degree' where 98.3\% of employees have a bachelor's degree, as well as with the variable 'presence of intranets', within which $96.7 \%$ of enterprises are partially or fully associated with this medium. When it comes to mid-sized enterprises, viewed by individual variables, the largest stocks of KM are registered in the variables 'number of employees with bachelor's degree' (100\%) and 'frequency of attending educational seminars outside the enterprise (94\%).

Keywords: Knowledge management; small and mid-sized Serbian enterprises; indicators for KM measurement; business efficiency 


\section{INTRODUCTION}

Knowledge is a strategic resource necessary for the prosperity of a modern enterprise. The importance of knowledge accumulation for the growth of profits and the development of entrepreneurial ideas was recognized by Paul Romer (1986; 2018). In modern business, knowledge is seen as a strategic asset (Halawi et al., 2005) by which competitive advantage is achieved in the market. Bearing in mind the growing importance of knowledge resources, the practice of KM, especially in small and medium enterprises, needs stronger scientific consideration (Durst \& Bruns, 2018). The main goal of this research paper is to determine the extent to which elements of KM are represented in small and mid-sized Serbian enterprises.

\section{LITERATURE REVIEW}

In search of competitive advantage, knowledge has positioned itself at the very top of resources that can improve the business of small and medium enterprises. The existing literature on KM has been mainly focused on large companies. In this study, the emphasis is on the application of KM in small and medium-sized enterprises. This chapter briefly presents a certain number of theoretical and empirical contemporary papers, important for the development of KM in small and medium-sized enterprises around the world.

Manfrinato and Albino (2009) presented a model for the implementation of KM in Brazilian small and medium-sized companies. According to the authors, KM should help smaller companies to maintain organizational memory and increase process efficiency. Elshaiekh and colleagues (2010) explained the impacts of KM on Sudanese small and medium-sized organizations. In the sample of 225 people in SMEs, the authors presented the impact of KM on different sectors, including processes, products, workers and general performance.

To adapt to a market economy, SMEs need to go through an adjustment process to meet the challenges of the knowledge economy (Litvaj \& Stancekova, 2015). This adaptation means a global move from an industrial to a knowledge society. The authors focused on just one particular change, namely the application of new and unused managerial strategies in a company - the embedment of KM in a company.

Aghimien and colleagues (2019) tried to determine the various factors that could serve as drivers towards achieving proper $\mathrm{KM}$ in small and medium construction companies of South Africa. A questionnaire was used as a methodological instrument for data collection in the study. The survey was carried out among staff members and stakeholders in management positions of grades 1 to 3 . According to the research results, the most needed drivers were strategic planning, building trust between stakeholders, attracting and retaining competent talent in the company and creating a competitive advantage that would help their growth in terms of the type of projects they engage in (ibid.). Tien and colleagues (2019) pointed to the importance of KM for the competitive advantage of Vietnam SMEs, which are often weak and lacking in this important resource. In the cluster analysis conducted on 223 companies in different European countries and sectors, three clusters were identified: 1 . companies that unconsciously implemented KM, 2. companies that more consciously introduced KM practices and 3. companies with a marginal 
propensity towards KM (Alexandru et al., 2019). On a sample of 217 workers in small and medium enterprises in Iraq, Abdulaali and colleagues (2019) proved that there was a positive relationship between intellectual capital and the success of small and medium enterprises. It was suggested that the learning and knowledge-based environment should improve the human capital level in order to enhance the survivability and economic stability of enterprises. According to Bolisani and Bratianu (2018), it is inevitable to have a new knowledge economy in a post-industrial society. The center of this economy is a knowledge-based company. In such a company, the pressure of efficiency and productivity should be replaced by new metrics able to measure the quality of knowledge and learning contribution to company performance. Croatian research (Buterin and Katavić, 2018) emphasized the importance of KM in the competitive advantage of companies. The study proved that companies that implement the KM system, achieve a competitive advantage over those that do not apply this practice. Milanovic-Glavan and Ivancic (2019) sought to determine the actual state of KM in Croatian companies with special emphasis on information technology. The state of the overall KM in Croatia was presented through empirical research including 200 companies. Slavkovic and Babic (2020), based on empirical research, pointed to the positive impact of KM on organizational performance, process innovation and administrative innovation of leading Serbian companies. Stojanovic-Aleksic and colleagues (2019) pointed out the importance of organizational structure and culture for the development of KM in Serbian companies. In a sample of $\mathbf{1 5 0}$ respondents and $\mathbf{3 0}$ companies, the authors proved that the organic structure and the organizational culture that support knowledge have positive effects on knowledge creation, while knowledge sharing is positively influenced only by the knowledge supporting culture of an organization (ibid.). The authors attempted to set up a model of key factors of knowledge infrastructure capability in SMEs in a transitional socioeconomic environment. Uzelac and colleagues (2018), tried to set up a model of key factors of knowledge infrastructure capability in SMEs in a transitional socioeconomic environment. Conducted on a sample of 760 senior executives and employees from 86 SMEs in Serbia, this research represents an attempt to model and evaluate the KM capabilities.

Our research started from the following hypothesis:

H: A knowledge management strategy is being implemented in Serbian small and medium enterprises.

\section{SURVEY STRATEGY}

\subsection{Sample Design and Data Collection}

The chapter analyzes the results of research on KM stocks in Serbian companies, with special reference to small and medium enterprises. The Serbian sample included 157 companies in the following economically important cities: Belgrade, Novi Sad, Niš, Kragujevac, Kraljevo, Užice, Subotica, Zrenjanin, Vranje, Leskovac, Jagodina, Ćuprija, Priboj, Pančevo and Šabac. In the selection of companies, the authors made sure to maintain a realistic ratio in the number of micro, small, medium and large companies in Serbia in the sample. 
The sample included 37 micro, 60 small, 34 medium-sized enterprises and 26 large companies. The sample covered five economic sectors: industrial, construction, IT, commercial and services. The criteria from the applicable Law on Accounting (The Government of the Republic of Serbia, 2013) were used in defining a company's size. The selection of companies in the sample was made from the list of the Business Directory of Serbia (Stojanovic, 2020) using the simple random sample method without repetition. The questionnaire was used as a methodological instrument for data collection. The questionnaire contained interval scales, Likert scales and closed answers. Managers of selected companies were surveyed. The questionnaire was distributed online in the period from 20 January to 20 February 2020. Data were processed in SPSS 25 by using the "custom tables with column proportion of significance" statistical technique (Field, 2013; Landau \& Everitt, 2004).

\subsection{The Model}

The study started with the following model:

$$
K M_{\text {stock }}=E_{i}+T_{i}+S t_{i}+D_{i}+S p_{i}
$$

Where, for $i=n$ observations:

$E_{i}=$ academic education of employees

$T_{i}=$ employees' training

$S t_{i}=$ storage

$D_{i}=$ dissemination

$S p_{i}=$ technical support

KM stock consists of 11 variables grouped into 5 indicators. The first unit called "academic education" consists of three variables: the share of employees in the company with bachelor's, master's and PhD degrees. The second unit called "employees' training" consists of the following variables: attending seminars and courses outside of the company, as well as attending educational seminars and courses within the company. The third thematic unit called "storage" consists of the following variables: the presence of an organized procedure for storing the necessary knowledge useful for the functioning of the company and the existence of a system for protection and registration of innovative solutions and procedures (at the Intellectual Property Office). The fourth unit called "dissemination" contains two variables: the obligation of participants in innovative knowledge seminars to report to departments, sectors or direct colleagues the results, as well as a variable that measures the obligation of the employees to inform coworkers about the results concerning the company's activities, upon returning from a business trip (after visiting fairs, exhibitions and other business events). The fifth unit called "technical support" consists of two variables. The first variable measures the possibility to access an intranet in companies, while the other measures the possibility to access virtual libraries and knowledge bases. The following operational criterion for rejecting the basic hypothesis $H$ was defined: In three of the five KM indicators, the share of 50\%+ companies have no KM stock; Observed at the level of indicators consisting of three variables, in two variables the presence of KM stocks does not exist in more than $50 \%$ of small and medium enterprises. 


\subsection{Results}

Based on the results, in $98.3 \%$ of small businesses, there were employees with bachelor's degrees (Table 1). The largest number of employees with a bachelor's degree (65\%) was in the contingent of 11 and more employees. When it comes to mid-sized enterprises, all interviewed companies had employees with bachelor's degrees. The largest number (59.9\%) was concentrated in a contingent of 11 and more employees.

\section{Table 1. Number of employees with a bachelor's degree}

\section{Comparison of column proportions ${ }^{b}$}

\begin{tabular}{|c|c|c|c|c|c|c|c|}
\hline & & & \multicolumn{5}{|c|}{ Company size } \\
\hline & & & Micro & Small & Medium & Large & Total \\
\hline & & & (A) & (B) & (C) & (D) & \\
\hline \multirow{5}{*}{$\begin{array}{l}\text { Number of } \\
\text { employees } \\
\text { with a } \\
\text { bachelor's } \\
\text { degree \% }\end{array}$} & 0 & Column N \% & $\begin{array}{c}13.5 \% \\
\text { (B) } \\
\end{array}$ & $1.7 \%$ & $0.0 \%$ & $0.0 \%$ & $3.8 \%$ \\
\hline & $1-5$ & Column N \% & $18.9 \%$ & $13.3 \%$ & $20.6 \%$ & $3.8 \%$ & $14.6 \%$ \\
\hline & $6-10$ & Column N \% & $5.4 \%$ & $20.0 \%$ & $23.5 \%$ & $23.1 \%$ & $17.8 \%$ \\
\hline & 11 and more & Column N \% & $62.2 \%$ & $65.0 \%$ & $55.9 \%$ & $73.1 \%$ & $63.7 \%$ \\
\hline & Total & Column N \% & $100.0 \%$ & $100.0 \%$ & $100.0 \%$ & $100.0 \%$ & $100.0 \%$ \\
\hline
\end{tabular}

Results are based on two-sided tests. For each significant pair, the key to the category with the smaller column proportion appears in the category with the larger column proportion.

The significance level for upper case letters (A, B, C): .05

b. Tests are adjusted for all pairwise comparisons within a row of each innermost subtable using the Bonferroni correction.

Source: Authors' calculation

Table 2 shows the number of employees with a MSc/MA degree. In $61.7 \%$ of small enterprises, there were employees with master's degrees. $26.7 \%$ of small enterprises claimed that they employed 11 or more employees with this type of education. When it comes to medium-sized companies, the situation was somewhat different. $88.2 \%$ of these companies had employees with master's degrees. According to the results, the largest number $(50 \%)$ of medium-sized companies said that they employed 1-5 employees with a master's degree. 
Table 2. Number of employees with a master's degree

Comparison of column proportions ${ }^{b}$

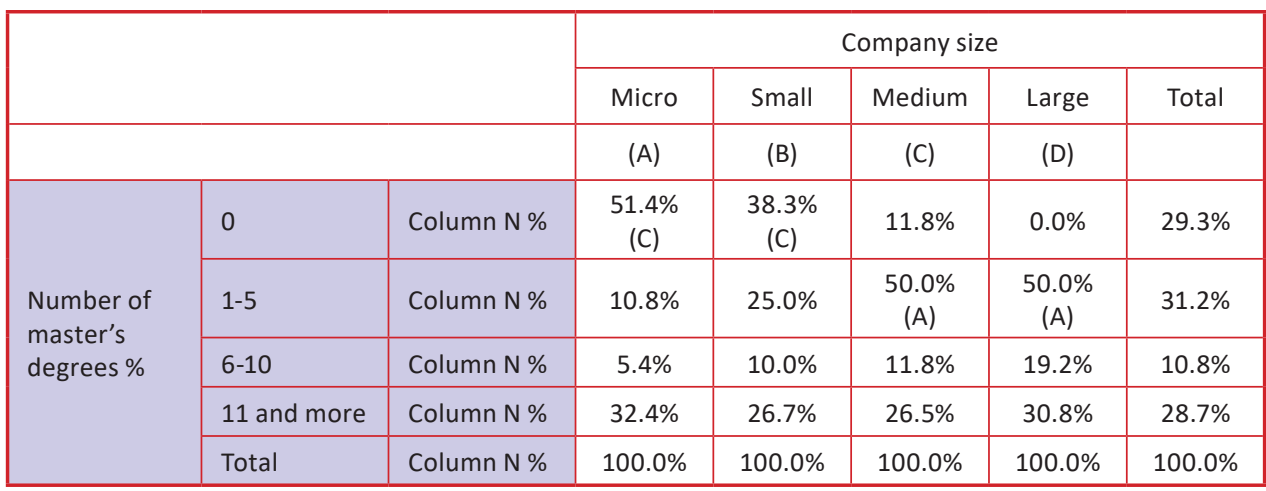

Results are based on two-sided tests. For each significant pair, the key to the category with the smaller column proportion appears in the category with the larger column proportion.

The significance level for upper case letters (A, B, C): .05

b. Tests are adjusted for all pairwise comparisons within a row of each innermost subtable using the Bonferroni correction.

Source: Authors' calculation

Table 3 shows the number of employees with a doctoral degree by company size. In $91.7 \%$ of small enterprises, there were no employees with this type of diploma. Based on the results, in $67.6 \%$ of medium-sized companies, there were no employees with PhD degrees, while in $32.4 \%$ of companies, there were $1-3$ employees with this type of diploma.

\section{Table 3. Number of employees with a PhD degree}

Comparison of column proportions ${ }^{b}$

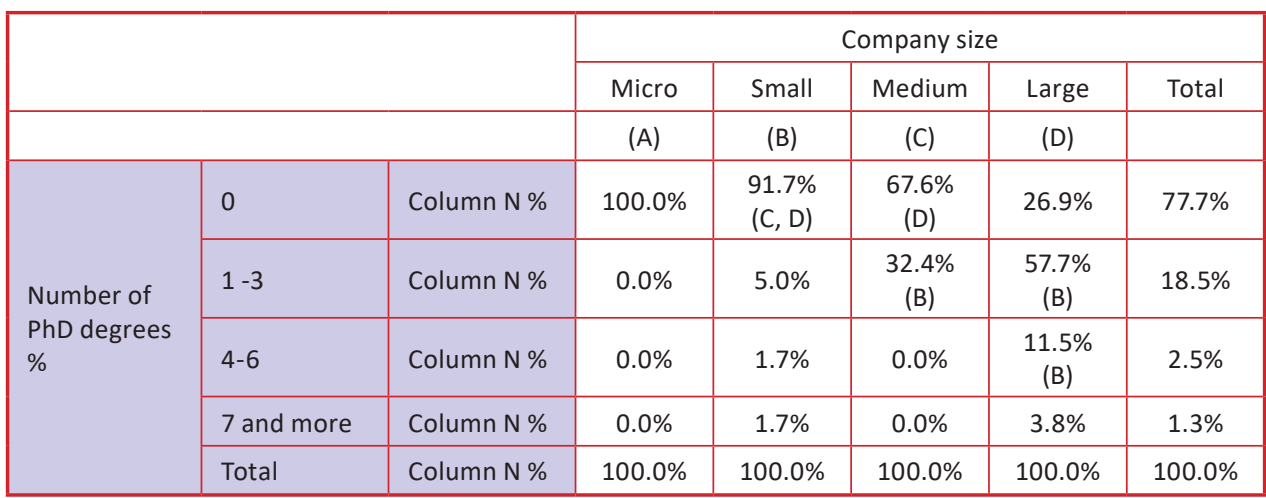

Results are based on two-sided tests. For each significant pair, the key to the category with the smaller column proportion appears in the category with the larger column proportion.

The significance level for upper case letters (A, B, C): .05

b. Tests are adjusted for all pairwise comparisons within a row of each innermost subtable using the Bonferroni correction.

Source: Authors' calculation 
Based on the results in Table 4, in $80 \%$ of small enterprises, employees were sent to seminars and courses outside the companies. $56.7 \%$ of companies sent a contingent of 1-10 employees to this type of training. In $94.1 \%$ of medium-sized companies, seminars and courses were organized for employees. $73.5 \%$ of companies sent a contingent of 1-10 employees to this type of training.

\section{Table 4. Attending seminars and courses outside the company}

Comparison of column proportions ${ }^{b}$

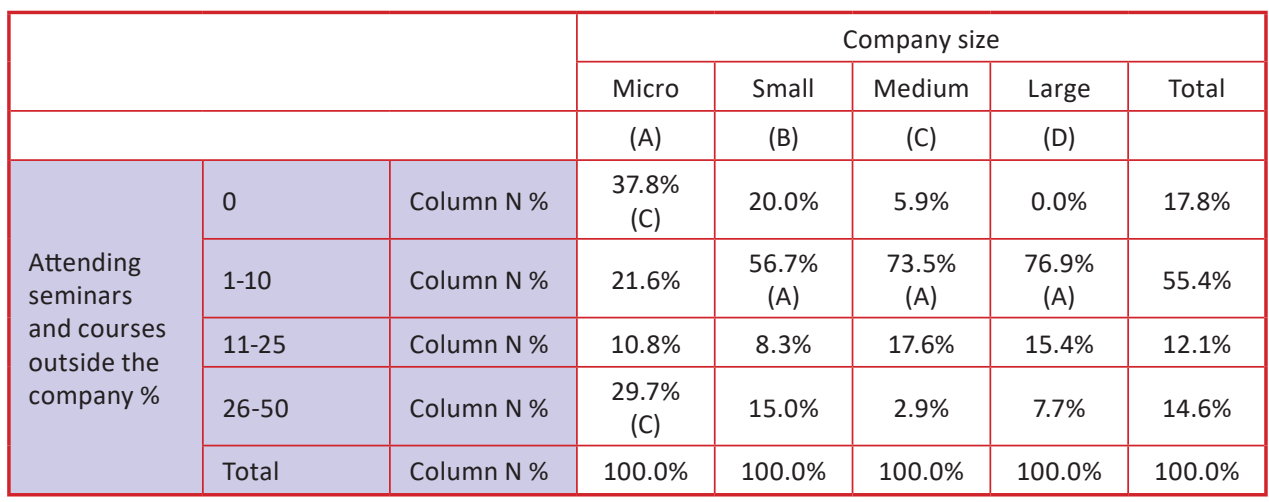

Results are based on two-sided tests. For each significant pair, the key to the category with the smaller column proportion appears in the category with the larger column proportion.

The significance level for upper case letters $(A, B, C): .05^{b}$

b. Tests are adjusted for all pairwise comparisons within a row of each innermost subtable using the Bonferroni correction.

Source: Authors' calculation

Table 5 shows attending educational seminars and courses in the companies. Based on the results, this type of knowledge acquisition was organized in $78.3 \%$ of small enterprises. $28.3 \%$ of small businesses organized seminars and courses for a contingent of 26 to 50 employees. 
Table 5. Attending educational seminars and courses in the company

Comparison of column proportions

\begin{tabular}{|c|c|c|c|c|c|c|c|}
\hline & & & \multicolumn{5}{|c|}{ Company size } \\
\hline & & & Micro & Small & Medium & Large & Total \\
\hline & & & (A) & (B) & (C) & (D) & \\
\hline \multirow{5}{*}{$\begin{array}{l}\text { Attending } \\
\text { educational } \\
\text { seminars and } \\
\text { courses in } \\
\text { the company } \\
\%\end{array}$} & 0 & Column N \% & $\begin{array}{l}40.5 \% \\
\text { (D) }\end{array}$ & $21.7 \%$ & $20.6 \%$ & $7.7 \%$ & $23.6 \%$ \\
\hline & $1-10$ & Column N \% & $16.2 \%$ & $26.7 \%$ & $41.2 \%$ & $34.6 \%$ & $28.7 \%$ \\
\hline & $11-25$ & Column N \% & $10.8 \%$ & $23.3 \%$ & $14.7 \%$ & $7.7 \%$ & $15.9 \%$ \\
\hline & $26-50$ & Column N \% & $32.4 \%$ & $28.3 \%$ & $23.5 \%$ & $50.0 \%$ & $31.8 \%$ \\
\hline & Total & Column N \% & $100.0 \%$ & $100.0 \%$ & $100.0 \%$ & $100.0 \%$ & $100.0 \%$ \\
\hline
\end{tabular}

Results are based on two-sided tests. For each significant pair, the key to the category with the smaller column proportion appears in the category with the larger column proportion.

The significance level for upper case letters (A, B, C): .05

Source: Authors' calculation

According to the results, $79.4 \%$ of medium-sized companies organized this type of knowledge acquisition for employees. $41.2 \%$ of medium-sized companies organized seminars and courses for 1-10 employees.

Based on the results, in $80 \%$ of small enterprises, there were organized procedures for storing the necessary knowledge useful for the functioning of the company (Table 6). In $41.7 \%$ of small enterprises, there was partial storage of the necessary data and procedures, while in $23.3 \%$, it was fully represented. 
Table 6. Organized procedures for storing necessary knowledge useful for the functioning of the company

Comparison of column proportions

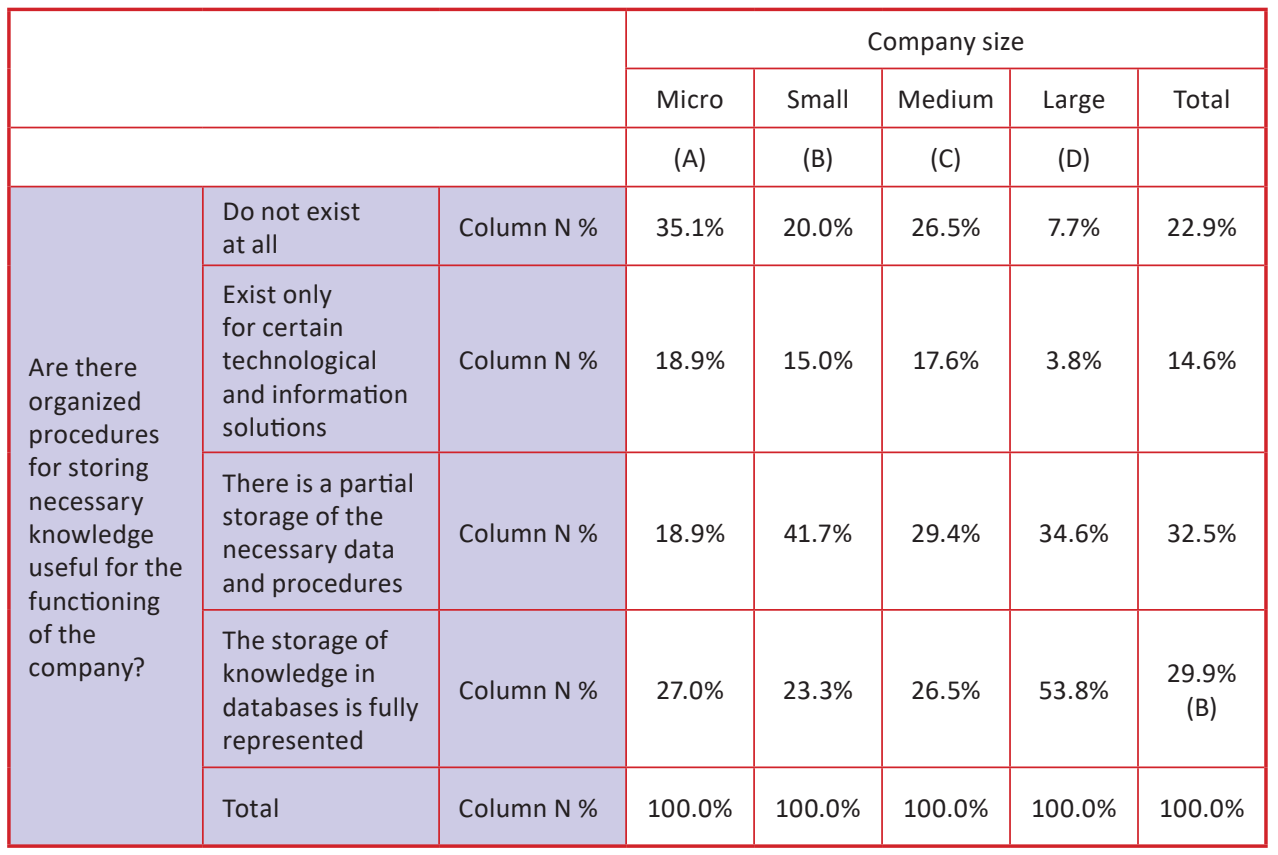

Results are based on two-sided tests. For each significant pair, the key to the category with the smaller column proportion appears in the category with the larger column proportion.

The significance level for upper case letters (A, B, C): .05

Source: Authors' calculation

In $73.5 \%$ of medium-sized companies, the mentioned procedures existed. In the largest number of companies (29.4\%) partial storage of data and procedures was represented.

Table 7 shows how much the system of protection and registration of innovative solutions and procedures in the authorized institution was represented in the companies. Based on the data, $63.3 \%$ of small enterprises did not have the mentioned protection system. Observed in medium-sized enterprises, in $53.8 \%$ this measure was also not present. 
Table 7. Is there a system of protection and registration of innovative solutions and procedures in the authorized institution?

Comparison of column proportions

\begin{tabular}{|c|c|c|c|c|c|c|c|}
\hline & & & \multicolumn{5}{|c|}{ Company size } \\
\hline & & & Micro & Small & Medium & Large & Total \\
\hline \multirow{5}{*}{$\begin{array}{l}\text { Is there a } \\
\text { system of } \\
\text { protection } \\
\text { and } \\
\text { registration } \\
\text { of innovative } \\
\text { solutions and } \\
\text { procedures } \\
\text { (at the } \\
\text { Intellectual } \\
\text { Property } \\
\text { Office)? }\end{array}$} & $\begin{array}{l}\text { Does not } \\
\text { exist at all }\end{array}$ & Column N \% & $73.0 \%$ & $63.3 \%$ & $58.8 \%$ & $42.3 \%$ & $61.1 \%$ \\
\hline & $\begin{array}{l}\text { It is } \\
\text { presented } \\
\text { only in } \\
\text { exceptional } \\
\text { cases }\end{array}$ & Column N \% & $10.8 \%$ & $16.7 \%$ & $26.5 \%$ & $15.4 \%$ & $17.2 \%$ \\
\hline & $\begin{array}{l}\text { It is } \\
\text { presented } \\
\text { partially }\end{array}$ & Column N \% & $13.5 \%$ & $8.3 \%$ & $5.9 \%$ & $19.2 \%$ & $10.8 \%$ \\
\hline & $\begin{array}{l}\text { It is totally } \\
\text { presented }\end{array}$ & Column N \% & $2.7 \%$ & $11.7 \%$ & $8.8 \%$ & $23.1 \%$ & $10.8 \%$ \\
\hline & Total & Column N \% & $100.0 \%$ & $100.0 \%$ & $100.0 \%$ & $100.0 \%$ & $100.0 \%$ \\
\hline
\end{tabular}

Source: Authors' calculation

Upon return from the seminar, in $81.7 \%$ of small enterprises, participants in innovative knowledge seminars had the obligation to report the results to the department, sector or direct colleagues (Table 8). In the majority of cases (36.7\%), participants always did so. In $88.2 \%$ of medium-sized enterprises, participants had the mentioned obligation. In $50 \%$ of companies, seminar participants partially implemented this obligation, while in $23.5 \%$ of companies they always fulfilled it. 
Table 8. Do participants in innovative knowledge seminars have the obligation to report the results to the department, sector or direct colleagues?

\begin{tabular}{|c|c|c|c|c|c|c|c|}
\hline & & & \multicolumn{5}{|c|}{ Company size } \\
\hline & & & Micro & Small & Medium & Large & Total \\
\hline & & & (A) & (B) & (C) & (D) & \\
\hline & Never & $\begin{array}{l}\text { Column } \\
\mathrm{N} \%\end{array}$ & $\begin{array}{l}37.8 \% \\
\text { (D) }\end{array}$ & $18.3 \%$ & $11.8 \%$ & $3.8 \%$ & $19.1 \%$ \\
\hline $\begin{array}{l}\text { in innovative } \\
\text { knowledge } \\
\text { seminars have }\end{array}$ & $\begin{array}{l}\text { In } \\
\text { exceptional } \\
\text { cases }\end{array}$ & $\begin{array}{l}\text { Column } \\
\mathrm{N} \%\end{array}$ & $16.2 \%$ & $10.0 \%$ & $14.7 \%$ & $7.7 \%$ & $12.1 \%$ \\
\hline $\begin{array}{l}\text { to report the } \\
\text { results to the }\end{array}$ & Partially & $\begin{array}{l}\text { Column } \\
\mathrm{N} \%\end{array}$ & $18.9 \%$ & $35.0 \%$ & $\begin{array}{l}50.0 \% \\
(\mathrm{~A})\end{array}$ & $\begin{array}{l}57.7 \% \\
\text { (A) }\end{array}$ & $38.2 \%$ \\
\hline $\begin{array}{l}\text { department, } \\
\text { sector }\end{array}$ & Always & $\begin{array}{l}\text { Column } \\
\mathrm{N} \%\end{array}$ & $27.0 \%$ & $36.7 \%$ & $23.5 \%$ & $30.8 \%$ & $30.6 \%$ \\
\hline colleagues? & Total & $\begin{array}{l}\text { Column } \\
\mathrm{N} \%\end{array}$ & $100.0 \%$ & $100.0 \%$ & $100.0 \%$ & $100.0 \%$ & $100.0 \%$ \\
\hline
\end{tabular}

Results are based on two-sided tests. For each significant pair, the key to the category with the smaller column proportion appears in the category with the larger column proportion.

The significance level for upper case letters (A, B, C): .05

Source: Authors' calculation

Based on the results of the research, in $90 \%$ of small enterprises, upon returning from business trips, the employees were obliged to inform coworkers about the results concerning the company's activities (Table 9 ). In 55\% of these companies, there was always this type of obligation. In $91.2 \%$ of medium-sized enterprises, upon returning from business trips the employees were obliged to inform coworkers about the results concerning the company's activities. In $50 \%$ of medium-sized companies, this obligation was partially represented. 
Table 9. Upon returning from business trips, are employees obliged to inform coworkers about the results concerning the company's activities?

Comparison of column proportions ${ }^{b}$

\begin{tabular}{|c|c|c|c|c|c|c|c|}
\hline & & & \multicolumn{5}{|c|}{ Company size } \\
\hline & & & Micro & Small & Medium & Large & Total \\
\hline & & & (A) & (B) & (C) & (D) & \\
\hline \multirow{5}{*}{$\begin{array}{l}\text { Upon returning } \\
\text { from business } \\
\text { trips (after } \\
\text { visiting fairs, } \\
\text { exhibitions and } \\
\text { other business } \\
\text { events), are } \\
\text { employees } \\
\text { obliged to inform } \\
\text { coworkers about } \\
\text { the results } \\
\text { concerning } \\
\text { the company's } \\
\text { activities? }\end{array}$} & Never & Column N \% & $18.9 \%$ & $10.0 \%$ & $8.8 \%$ & $0.0 \%$ & $10.2 \%$ \\
\hline & $\begin{array}{l}\text { In } \\
\text { exceptional } \\
\text { cases }\end{array}$ & Column N \% & $8.1 \%$ & $10.0 \%$ & $17.6 \%$ & $11.5 \%$ & $11.5 \%$ \\
\hline & Partially & Column N \% & $16.2 \%$ & $25.0 \%$ & $\begin{array}{c}50.0 \% \\
\text { (A) }\end{array}$ & $30.8 \%$ & $29.3 \%$ \\
\hline & Always & Column N \% & $\begin{array}{c}56.8 \% \\
(C)\end{array}$ & $\begin{array}{c}55.0 \% \\
\text { (C) }\end{array}$ & $23.5 \%$ & $\begin{array}{c}57.7 \% \\
\text { (C) }\end{array}$ & $49.0 \%$ \\
\hline & Total & Column N \% & $100.0 \%$ & $100.0 \%$ & $100.0 \%$ & $100.0 \%$ & $100.0 \%$ \\
\hline
\end{tabular}

Results are based on two-sided tests. For each significant pair, the key to the category with the smaller column proportion appears in the category with the larger column proportion.

The significance level for upper case letters (A, B, C): $.05^{\mathrm{b}}$

b. Tests are adjusted for all pairwise comparisons within a row of each innermost subtable using the Bonferroni correction.

Source: Authors' calculation

According to the results, $70 \%$ of small businesses had access to virtual libraries and knowledge bases (Table 10). In 33.3\% of companies, there was partial access to these media. When it comes to medium-sized companies, the situation was somewhat more unfavorable. $55.9 \%$ of these companies had access, while only $14.4 \%$ had full access to virtual libraries and knowledge bases. 
Table 10. Access to virtual libraries and knowledge bases

Comparison of column proportions

\begin{tabular}{|c|c|c|c|c|c|c|c|}
\hline & & & \multicolumn{5}{|c|}{ Company size } \\
\hline & & & Micro & Small & Medium & Large & Total \\
\hline \multirow{5}{*}{$\begin{array}{l}\text { Is there access } \\
\text { to virtual } \\
\text { libraries and } \\
\text { knowledge } \\
\text { bases? }\end{array}$} & $\begin{array}{l}\text { Does not } \\
\text { exist }\end{array}$ & $\begin{array}{l}\text { Column } \\
\mathrm{N} \%\end{array}$ & $40.5 \%$ & $30.0 \%$ & $44.1 \%$ & $34.6 \%$ & $36.3 \%$ \\
\hline & $\begin{array}{l}\text { In } \\
\text { exceptional } \\
\text { cases }\end{array}$ & $\begin{array}{l}\text { Column } \\
\mathrm{N} \%\end{array}$ & $5.4 \%$ & $8.3 \%$ & $14.7 \%$ & $7.7 \%$ & $8.9 \%$ \\
\hline & Partially & $\begin{array}{l}\text { Column } \\
\mathrm{N} \%\end{array}$ & $37.8 \%$ & $33.3 \%$ & $26.5 \%$ & $19.2 \%$ & $30.6 \%$ \\
\hline & $\begin{array}{l}\text { There is full } \\
\text { access }\end{array}$ & $\begin{array}{l}\text { Column } \\
\mathrm{N} \%\end{array}$ & $16.2 \%$ & $28.3 \%$ & $14.7 \%$ & $38.5 \%$ & $24.2 \%$ \\
\hline & Total & $\begin{array}{l}\text { Column } \\
\mathrm{N} \%\end{array}$ & $100.0 \%$ & $100.0 \%$ & $100.0 \%$ & $100.0 \%$ & $100.0 \%$ \\
\hline
\end{tabular}

Source: Authors' calculation

According to the results, $96.7 \%$ of small enterprises had some kind of intranet connection (Table 11). In $76.7 \%$ of companies, employees were fully connected via intranet. $88.2 \%$ of medium-sized companies had an intranet connection. In most companies (76.5\%), employees were fully connected through this medium.

\section{Table 11. Connection via intranet}

Comparison of column proportions ${ }^{b}$

\begin{tabular}{|c|c|c|c|c|c|c|c|}
\hline & & & \multicolumn{5}{|c|}{ Company size } \\
\hline & & & Micro & Small & Medium & Large & Total \\
\hline \multirow{4}{*}{$\begin{array}{l}\text { Are you } \\
\text { connected via } \\
\text { intranet? }\end{array}$} & $\begin{array}{l}\text { Does not } \\
\text { exist }\end{array}$ & $\begin{array}{l}\text { Column } \\
\mathrm{N} \%\end{array}$ & $5.4 \%$ & $3.3 \%$ & $11.8 \%$ & $0.0 \%$ & $5.1 \%$ \\
\hline & $\begin{array}{l}\text { There is } \\
\text { partial } \\
\text { connection }\end{array}$ & $\begin{array}{l}\text { Column } \\
\mathrm{N} \%\end{array}$ & $13.5 \%$ & $20.0 \%$ & $11.8 \%$ & $34.6 \%$ & $19.1 \%$ \\
\hline & $\begin{array}{l}\text { We are fully } \\
\text { connected } \\
\text { via the } \\
\text { intranet }\end{array}$ & $\begin{array}{l}\text { Column } \\
\mathrm{N} \%\end{array}$ & $81.1 \%$ & $76.7 \%$ & $76.5 \%$ & $65.4 \%$ & $75.8 \%$ \\
\hline & Total & $\begin{array}{l}\text { Column } \\
\mathrm{N} \%\end{array}$ & $100.0 \%$ & $100.0 \%$ & $100.0 \%$ & $100.0 \%$ & $100.0 \%$ \\
\hline
\end{tabular}

Results are based on two-sided tests. For each significant pair, the key to the category with the smaller column proportion appears in the category with the larger column proportion.

The significance level for upper case letters (A, B, C): .05

b. Tests are adjusted for all pairwise comparisons within a row of each innermost subtable using the Bonferroni correction.

Source: Authors' calculation 
Based on the results for small and mid-sized enterprises, measurement indicators such as "employee training", "dissemination" and "technical support" showed a positive level, while the "storage" and "academic education" indicators had a partial presence of KM stocks. When it comes to small enterprises, in terms of individual variables that were a constituent part of indicators, the largest stocks of KM were measured with the variable "number of employees with a bachelor's degree", where $98.3 \%$ of employees had a bachelor's degree, as well as with the variable "presence of intranets", within which $96.7 \%$ of enterprises were partially or fully associated with this medium. When it comes to midsized enterprises, viewed by individual variables, the largest stocks of KM were registered in the variables "number of employees with a bachelor's degree" $(100 \%)$ and "frequency of attending educational seminars outside the enterprise (94\%). It was concluded that hypothesis $H$ was confirmed.

\section{DISCUSSION}

The main goal of the research was to determine whether a KM strategy is represented in small and mid-sized Serbian enterprises. In three of the five indicators for measurement, there were stocks of KM. In the indicators "storage" and "academic education", the presence of KM was partial. If the results are compared with the research of KM in Croatian companies (Milovanovic-Glavan \& Ivancic, 2019), despite a slightly different methodological approach, certain differences in the results could be noticed. The results of the research conducted in Croatian companies showed that a trend of KM existed in Croatia, but also that there was a potential for further development. It was shown that Croatian companies had the lowest grade for the IT aspect of KM. Serbian results for variables connecting KM and IT, such as procedures for storing necessary knowledge useful for the functioning of the company, the presence of virtual libraries and intranet connections, showed the presence of solid stocks of KM. The research that included 6 Croatian companies (Buterin \& Katavić, 2018) confirmed the implementation of the KM system in 5 companies. On average, $87 \%$ of employees of the companies were involved in various forms of training. When compared to the results of the Serbian survey, in $82.2 \%$ of Serbian companies, employees went to seminars and courses outside the company, while $76.4 \%$ organized seminars and courses within the company. Although there were some differences in the methodological procedure, most Croatian and Serbian companies have recognized the importance of transferring knowledge at meetings, through reports and informal conversations, in order to run companies more efficiently.

Implementing a KM strategy in companies is often not an easy process and can lead to some employee resistance. The KM paradigm originates from the West. In the countries of Central and Eastern Europe, the KM concept began to be imported in the early 2000s, in parallel with the process of business globalization and the Third Industrial Revolution. The implementation of KM strategies has posed various challenges to CEE countries. One of them is the socio-cultural differences and specifics of the CEE countries in relation to the KM model imported from the West. In this regard, as a potential topic for future research, various questions arise, with the following standing out: does KM add value when directly exported to CEE, should the Western model be adapted to the specific target culture, is the original Western methodology of KM implementation 
in firms fully applicable in CEE and can CEE countries understand the issues of KM in their local context? In the time of Industry 4.0, in which knowledge is one of the most important resources, the introduction of a KM strategy in CEE companies is a necessary process. However, effective KM implementation implies that the processes of creation, organization, sharing and application of knowledge are harmonized with the specifics of the business and institutional culture of local countries.

\section{CONCLUSION}

In the time of the current Fourth Industrial Revolution, characterized by the technological possibility of an enormous flow of information, KM is an inevitable strategy for the success and market visibility of any company. When it comes to the level of knowledge stocks and achievement of a KM strategy in Serbian companies, based on the results of the research, they are at the very end of the initial, with a tendency to move to the developed phase soon. The development of awareness about the importance of knowledge has been influenced primarily by business globalization as well as managers who are responsible for the practical implementation of this strategy in this area. Besides, the exposure of knowledge in the mass media, as one of the basic drivers of the Industrial Revolution 4.0 , has a certain impact. 


\title{
ZALIHE MENADŽMENTA ZNANJA U MALIM I SREDNJIM SRPSKIM TVRTKAMA
}

\author{
dr. sc. Vojislav Babić \\ Univerzitet u Beogradu, Institut za sociološka istraživanja, \\ Čika Ljubina 18, 11000 Beograd, Srbija, \\ tel. +38163334067, e-mail:babic.voja@gmail.com \\ prof. dr. Siniša Zarić \\ Univerzitet u Beogradu, Ekonomski fakultet \\ Kamenička 6, 11000 Beograd, Srbija, \\ tel. +38163254525, e-mail: sinisha.zaric@gmail.com
}

\section{SAŽETAK}

Studija mjeri i analizira razinu zastupljenosti strategije upravljanja znanjem u srpskim tvrtkama. Upravljanje znanjem vještina je stjecanja i raspodjele resursa s ciljem postizanja veće poslovne učinkovitosti i profitabilnosti tvrtki. Rad polazi od Romerove $(1986,2018)$ teorije povećanja prinosa. Prema Romeru, stabilan rast rezultat je endogenog nakupljanja znanja. Cilj ovog rada je utvrditi u kojoj su mjeri elementi upravljanja znanjem zastupljeni u malim i srednjim srpskim tvrtkama. Izgrađen je instrument za mjerenje upravljanja znanjem koji sadrži 11 varijabli razvrstanih u 5 složenih pokazatelja: akademsko obrazovanje, obuka zaposlenika, skladištenje, širenje znanja i tehnička podrška. Za prikupljanje podataka korišten je online upitnik sa zatvorenim odgovorima, intervalskim i Likertovim ljestvicama. Istraživanje je provedeno na uzorku od 157 tvrtki u 15 gradova u Srbiji, od čega 60 malih i 34 srednje tvrtke. Podaci su obrađeni statističkom tehnikom „prilagođene tablice s udjelom stupaca značajnosti." Na temelju rezultata za mala i srednja poduzeća, u pokazateljima za mjerenje kao što su obuka zaposlenika, širenje znanja i tehnička podrška postoji pozitivna razina, dokje u pokazateljima „skladištenje" $i$ „,akademska edukacija“ djelomična prisutnost zaliha upravljanja znanjem. Kada je riječ o malim tvrtkama, s obzirom na pojedinačne varijable, koje su sastavni dio pokazatelja, najveće zalihe upravljanja znanjem izmjerene su u varijabli „broj sveučilišnih diplomanata“ gdje 98,3\% zaposlenih ima sveučilišnu diplomu, kao i u varijabli „prisutnost intraneta" u okviru koje je 96,7\% tvrtki djelomično ili potpuno povezano s ovim medijem. Kada je riječ o srednjim tvrtkama, glede pojedinačnih varijabli, najveće zalihe upravljanja znanjem registrirane su u varijablama „broj sveučilišnih diploma“ (100\%) $i$ „učestalost pohađanja obrazovnih seminara izvan tvrtke" (94\%).

Ključne riječi: Menadžment znanja; male i srednje srpske tvrtke; indikatori za mjerenje menadžmenta znanja; poslovna učinkovitost 


\section{REFERENCES}

1. Abdulaali, A., Alnoor, A. \& Eneizan, B. (2019). A Multi-Level Study of Influence Financial Knowledge Management Small and Medium Enterprises. Polish Journal of Management Studies, 19(1), 21-31. doi: 10.17512/pjms.2019.19.1.02

2. Aghimien, D., Gomes, F., Algabvoa, C. \& Thwala, E. (2019). Drivers of Knowledge Management in Small and Medium Construction Companies in South Africa. $14^{\text {th }}$ International Conference Organization, Technology and Management in Construction and IPMA $7^{\text {th }}$ Research Conference, Zagreb, Croatia. Preuzeto s https://www.researchgate.net/publication/335631834

3. Alexandru, V. A., Bolissani, E., Andrei, A., Cegarra-Navarro, G., Martínez, A. M., Paiola, M., Scarso, E., Vătămănescu, E. M. \& Zieba, M. (2019). Knowledge Management Approaches of Small and Medium-Sized Firms: A Cluster Analysis. Kybernetes, 49(1), 73--87. doi: 10.1108/K03-2019-0211

4. Bolisani, E. \& Bratianu, C. (2018). The Emergence of Knowledge Management. In E. Bolisani and C. Bratianu (Eds.), Emergent Knowledge Strategies: Strategic Thinking in Knowledge Management (pp. 23-48). Cham: Springer International Publishing

5. Buterin, R. \& Katavić, I. (2018). Utjecaj upravljanja znanjem na konkurentsku prednost poduzeća. Obrazovanje za poduzetništvo, 8(2), 39-55

6. Durst S., Bruns G. (2018). Knowledge Management in Small and Medium-Sized Enterprises. In: Syed J., Murray P., Hislop D., Mouzughi Y. (Eds.), The Palgrave Handbook of Knowledge Management (pp. 495-514). Cham: Palgrave Macmillan. doi:10.1007/978-3-319-71434-9_20

7. Elshaiekh, N., Woods, P. \& Murali Raman, M. (2010). The Impact of KM on Small and Medium Sized Organizations in Sudan. Journal of Information \& Knowledge Management, 9(1), 41-53. doi:10.1142/S0219649210002504

8. Field, A. P. (2013). Discovering Statistics Using IBM SPSS (4 $4^{\text {th }}$ Edition). London: Sage.

9. Halawi L, Aronson, J. \& McCarthy, R. (2005). Resource-Based View of Knowledge Management for Competitive Advantage. The Electronic Journal of Knowledge Management, 3(2), 75-86, . Preuzeto s www.ejkm.com

10. Landau, S. \& Everitt, B. (2004). A Handbook of Statistical Analyses Using SPSS. London: Chapman \& Hall

11. Litvaj, I. \& Stancekova, D. (2015). Knowledge Management Embedment in Company, Knowledge Repositories, Knowledge Management Significance and Usage in Company. Procedia Economics and Finance, 23, 833-838. doi: 10.1016/S2212-5671(15)00549-3

12. Manfrinato, A. \& Albino, J. (2009). Model for Knowledge Management in Small Companies: Case Study. POMS $20^{\text {th }}$ Annual Conference Orlando, Florida, U.S.A.

13. Milovanovic-Glavan, Lj. \& Ivancic, L. (2019). Knowledge Management: Case of Croatia. 46th International Scientific Conference on Economic and Social Development - "Sustainable Tourist Destinations" - Varazdin, 24-25 October

14. Romer, P. M. (1986). Increasing Returns and Long Run Growth. Journal of Political Economy, 94, 1002-37

15. Romer, P. M. (2018). "Facts". NobelPrize.org. Nobel Media AB 2019. Preuzeto s https://www. nobelprize.org/prizes/economic-sciences/2018/romer/facts/ 7/03/ 2019.

16. Slavkovic, M. \& Babic, V. (2020). Knowledge Management, Innovativeness, and Organizational Performance: Evidence from Serbia. Ekonomski anali, 58(199): 85-107. doi: 10.2298/ EKA1399085S

17. Stojanovic, G. (2020). Serbian Business Directory. Belgrade: Telcom. 
18. Stojanović-Aleksić, V., Erić Nielsen, J. \& Bošković, A. (2019). Organizational Prerequisites for Knowledge Creation and Sharing: Empirical Evidence From Serbia. Journal of Knowledge Management, 23(8), 1543-1565. doi:10.1108/JKM-05-2018-0286

19. The Government of the Republic of Serbia (2013). Accounting Law. Službeni glasnik RS, 62, 4-5. Preuzeto s http://www.infuse.co.rs/zakoni/z_racunovodstvo_62_2013.pdf

20. Tien, N., Thoi, B., Phong, V. \& Duc, Le Doan, M. (2019). Knowledge Management in Enhancing Competitiveness of Small and Medium Enterprises. International Journal of Research in Finance and Management, 2(2), 61-66. Preuzeto s https://www.allfinancejournal.com/article/ view/36/2-2-19

21. Uzelac, Z., Ćelić. Đ., Petrov, V., Drašković, Z. \& Berić, D. (2018). Comparative Analysis of Knowledge Management Activities in SMEs: Empirical Study from a Developing Country. Procedia Manufacturing, 17, 523-530. doi: 10.1016/j.promfg.2018.10.092 